\title{
Analysis of Public Environment in Ceramic Sculpture and Installation Art
}

\author{
Jin Xiang ${ }^{1}$ \\ ${ }^{1}$ Wuhan Institute of Design Engineering, Institute of Jackie Chan Film Multimedia, Wuhan, 430205 \\ 54892713@163.com
}

Keywords: Public Environment; Ceramic Sculpture; Installation Art

\begin{abstract}
Based on the design of urban public environment, this article exposed in public places spirit weak environment, low level of public art works flood, design issues such as ecological awareness is weak, with common characteristics and installation art and environmental design combined advantages of the above issues raised optimized solutions. Studies using art installations in urban public environment is designed to solve some of the problems or improve the environment in urban public today exposed as the ultimate goal. This article briefly describes the relationship between environment and application of ceramics.
\end{abstract}

\section{Introduction}

Environmental design and art will be in a winding way affect each other along. Environment (human environment + natural environment) to provide material for the arts and the occurrence conditions of artistic creation more borrowing in the natural environment, human environment is also an important motivation for the development of arts, the environment itself is also from an artistic point of view to understand the sidelines, and so on, two relations close and subtle. Although the environmental design disciplines involved more, but sometimes change the development of an artistic genre or art form might generate widespread environmental design far-reaching impact. Whether it is formal or philosophy, art environmental design offers many possibilities to explore beyond our imagination and presence, using study art installations in urban public environment that is based on the environment designed to provide new possibilities of a practice summary and Exploration.

Since the mid-20th century, a number of classic works of Brazilian artists garden Marquez, Mexico designer Barragan and Japanese-American sculptor Isamu Noguchi and other creation, have to show us the artistic ideas and creative ideas in the garden use. About installation art intervention in urban public environment, the international community has a number of landscape architects and artists made with varying degrees of exploration and practice. As we know is the American landscape architect Martha Schwartz • Since the 1980s installation art and landscape design will combine the last century created the most famous donuts garden landscape projects. And from Vietnam • Andy Cao and Xavier from France • Parrott partner in a multicultural background, giving the device in conjunction with the environment has brought a different texture and color experience. In addition, especially in the past 20 years, the emergence of many art installations around the world get a good use case and artists in the design of the urban environment, such as Jon • Piasecki and his Stones River, Ito and his public image Ceramics device giant rabbit Sweden Square, Bruce Munro • Wood Garden Design Lang have done to this end research to explore new and get a good reputation in the international community. Chinese architect Zhang and the second held in Japan "Echigo Tsumari Art Triennial" device works on the "rice house", strengthening, poetic conversion seasons, expressed local farmers and foreign tourists care . After the Shanghai Expo Park Park also appeared highly interactive landscape installations, to enhance the design quality of the whole park. With the power of installation art has been widely accepted, designers and even held a landscape installation art exhibition to explore the development direction of the landscape device. We can say that despite public art installations in urban environments using only the city environment design of an exploration, but this exhibit to explore urban design in the entire development process of a good growth momentum. $\mathrm{N}$ should be a sentence we often hear, installation art from the time birth, with a birthmark on the environment space. 


\section{Ceramic Sculpture and Public Environmental Art}

Ceramic sculpture relative to other materials, which itself has a lot of advantages. Ceramic sculpture is the art of the fire, after firing at high temperatures, corrosion resistance and freezing rain, high temperature characteristics, the ceramic sculpture will not be because of natural climate changes in corrosion in the structure, which also has a glaze permanent; ceramic sculpture glaze rich and varied, refreshing; glassy surface glazed ceramic sculpture fired at high temperature formed and easy to clean. Many advantages for long enough evidence ceramic sculpture placed outdoors. In the 15th and 16th centuries, due to the prevalence of religious buildings, the Italian ceramic sculpture and architecture fused into one and the whole Association. Sculpture, although not the subject, but carefully dressed church (there are a few secular buildings) of each wall studs. Today, public space has become part of our social and cultural whole. - Antonio Gaudi buildings Gill Park (Barcelona), the main entrance to the lizard sculpture pouring cement structure and shape, surface mount ceramic mosaics, sculpture strengthened by changes in the shape and decoration color texture, extending new visual and associative. Miro sculpture also uses some of this method. They offer a combination of ultimate expression in ceramics and architecture. Danish artist Bjorn Norgard art projects: some of the world's largest ceramic sculpture (30 meters high).

\section{Installation Art and Environment Pottery}

Installation art has become an important branch of contemporary art installation art, also known as "environmental art", began in the 1960s. Influenced by "Pop Art", "Minimalism" and "conceptual art", etc., the rapid development of installation art, contemporary art has been prevalent in the many painters and sculptors have joined the "installation art" in the ranks. In the West, there are specialized installation art galleries. Because many potters are also involved in the creation of installation art, making pottery also becomes an important means for language.

Apparatus and sculpture, although both are closely connected, but there are also differences: as a concrete entity and three-dimensional shape, the device is difficult to distinguish closely with sculpture. But the creation of objects and concepts factors, differences still exist between the two. Means are public art and sculpture, but independence sculpture in public spaces stronger than the means, pay more attention to the artist than the subtle expression of the heart device, which exists between the United States and three-dimensional shape, lines and techniques of characterization and implication. The means focuses on multi-dimensional field (environment) of the overall atmosphere, more emphasis on interactive artist whose work (environment) and among the audience, drawing the audience to participate, to face the people in a state of creative thinking.

Installation art and the environment have a profound link pottery. Qin Shi Wang horses commission can be regarded as China's most prominent environmental ancient pottery installations. Modern pottery device from Dada pioneer in Marshall • Toussaint) talked about his work, "spring" historic. Introduced in the works now finished ceramic products using signature urinals, and upside down, it is actually a ceramic device product. Starting in the 1980s, devices continue to penetrate into the ceramic field. In the United States, Japan and other countries appeared to ready-made ceramics, industrial waste ceramic, composite materials and the production of clay without firing installations. Because of this grand vision, field and dreamy state of mind marginalized, since the 1980s, more and more artistic style means potters who favor. Modern pottery as part of modern art, this exchange is the most natural thing to do. Japan Nakamura Jin Ping is the use of ready-made ceramics internationally renowned potters. Ceramics device works on its use of a variety of ceramic products daily life, such as handicrafts, bathroom tiles, porcelain industry, and its nearly 30 years of good work and so abandoned. In a nearly 500-square-meter field, he mainly uses these readymade related concepts, images, styles and techniques, and beaten constitute a "hodgepodge." Nearly a decade, in Germany also prevailed pottery field installation art style. Plaid Bernhard Johannes prefabricated, used industrial products (such as high temperature kiln and brick kilns) and other ceramics to create temples and monuments. 


\section{Installation Art Creative Ideas in Urban Public Environmental Design}

Readymade Art Fight Set. After the urban public environment, "landscape means", also known as the "environment means" is a public art installations in urban environmental design can reflect a certain theme of landscape, the landscape better interpretation of the spirit of place, deepen and human thought communication, and enhance the quality of the artistic landscape workplace applications. It is a rich visual experience, psychological suggestion, sensory exposure and focus on the emotional exchange constitutes participation in the urban landscape, is rich connotation of urban landscape, urban population constitutes an integral part of the high quality of life exquisite props.

The Emphasize of the Device Concept. In theory, people and places on the body's own perception of the exchange system arising under the initial interaction between man and because of some abstract meaning conveyed by the works resonate on a spiritual point and moved. However, the conventional design experience tells us that emotion comes from the designer's expression may not be able to get the viewer's identity, AC does not mean eventually resonate. To generate a spirit of sympathy because, as inevitably inseparable from communication and exchange of people following the spirit of the place [8] and place two processes determine the face of identity. A very important thing can not be ignored - design standards directly affect depth of communication. Communication process people and places and fracture due to design standards, the identity of the second process tends to balance direct negation of works, how to impress?

Constraints landscape design standards of many factors, the four principles of urban design in the public environment, holistic, ecological, humane and designed to meet a variety of physiological and psychological needs for the crowd from different angles, no one did not test properly have a direct impact on the actual outcome of the design. The contemporary urban design there is a more important issue is the public environmental places of spiritual light. It is a direct manifestation of Environmental Design apathy and low public satisfaction, such establishments have not built up the environment and people's sense of affinity and belonging. Cause such consequences from a wide range of constraints, we are helpless in which many aspects, but one thing is from the designers themselves, that designers in the design process is likely to ignore the spirit of place and a venue for the spirit of place the importance of the use of the crowd, and even some designers have been driven by the interests and power to disregard the importance of the spirit of place, but it means the artist can not.

Waste Recycling is Now Finished. In downtown Denver, there have been a group of installations used office furniture and fresh green plants constitute the "natural system of dominance," which is a group of dominant Device of office space and natural systems. Our living environment has long been too much office space is dominated bondage. But if we have considered whether to let the system play its dominant nature, humanity and nature is in a kind of relationship? In fact, we are farther away from the natural mean more incompatible with the whole nature of our system, and ultimately produce irreconcilable contradictions. So designers encourage people out of the office at rest, to breathe the nature, close to the green, too wary of office space to expand healthy relationships affect people and the outdoor environment.

Common man and nature is included in a closed ecosystem. All along, the man must get in the circle of the entire ecosystem energy from nature, but with the gradual transformation of the way of human existence, from hunter-gatherers to agricultural products to the energy of today's post-industrial society, the intensity of energy demand growing, nature reserves in the resource-intensive lifestyles modern continuous consumption, thus resulting in environmental pollution, energy crisis and other issues, and more serious. So along with the 1962 Rachel • Card Motion "Silent Spring," a book published, along with a modern ecological revolution detonated. In this context, artists from around the world also have the power to make the relevant policy responses and solutions. For example, George libraries • Logan proposed the corresponding waste recovery and recycling program. Faced with pollution everywhere felled trees, waters, soil and water and toxic waste piled dirt drain, how humans in the natural constraints such an interconnected complex biological and cultural survival, how to balance their relationship, so The orderly and 
healthy development can continue, it would be installation art and landscape design coincides with topics of common concern.

\section{Conclusion}

Art installations in urban public environment actually is a new interpretation of the urban public environment posed it to solve practical problems or relieve major aim, in view of today's urban public environment, the landscape has exposed a weak spirit of place made, low level of public art works spread, the design concept of ecological awareness is weak, not strong sense of innovation and design practice and many other issues a positive response to their own advantages to provide an effective solution; and activating landscape showing necrotic areas in practice, additional value options, it offers an alternative way to experience and create strange landscape, enhance the interaction attribute places emphasis on sustainability and saving capital costs of materials and many other advantages, inclusive of contemporary art and its own advantages again and again to bring people surprise.

\section{References}

[1] Edmund N. Bacon . Design of Cities: Revised Edition. Penguin (Non-Classics), 1976.

[2] Le Corbusier. The City of Tomorrow and Its Planing. The Architectural Press, 1987.

[3] Jane Jacobs. The Death and Life of Great American Cities. Random House, 1961.

[4] Jan Gehl. Life between Buildings Using Public Space. Island Press, 2008.

[5] San Li. Interior Design Reed. Elsevier, Inc. New York, 2004, (9). 